\title{
See-saw nystagmus
}

\author{
DAVID A. DRACHMAN
}

From the Department of Neurology and Psychiatry, Northwestern University Medical School, Chicago, Ill., U.S.A.

See-saw nystagmus is a rare ocular abnormality, only 15 cases having been recorded to date (Maddox, 1914; Rucker, 1946; Larsen, 1957; Jensen, 1959; Smith and Mark, 1959; Mark, Smith, and Kjellberg, 1960; Lourie, 1963; Schurr, 1963; Kinder and Howard, 1963; Slatt and Nykiel, 1964; and Daroff, 1965). As initially described by Maddox (1914), the eye movements consist of regular reciprocating oscillations in which one eye rises while the other falls. Torsion of the eyes accompanies the vertical movements so that the axis of the rising eye intorts while that of the falling eye extorts.

Nine of the reported cases of see-saw nystagmus have been associated with tumours in the region of the optic chiasm and diencephalon. These lesions do not entirely explain the pathogenesis of the seesaw movement, however, since in other cases brainstem or ocular lesions were described instead. Furthermore, in innumerable parasellar lesions seesaw nystagmus does not occur. Much still remains to explain the pathophysiology of see-saw ocular movements.

The purpose of the present communication is to present an additional case in which see-saw nystagmus was observed in a patient with bitemporal hemianopia and abnormal vestibular responses. Attention is directed to several of the previously reported cases in which abnormal vestibular responses were also noted. A mechanism is suggested by which see-saw nystagmus is produced by various combinations of visual, vestibular, or other lesions rather than by a lesion in a single anatomical site.

\section{CASE REPORT}

HISTORY A 65-year-old woman was well until 1957 when she noticed the insidious onset of visual impairment in both eyes. In 1963 she was admitted to another hospital where radiographs revealed enlargement of the sella turcica; examination of the visual fields demonstrated bitemporal hemianopia. Neurological examination was otherwise within normal limits and lumbar puncture revealed no abnormalities. An endocrine evaluation showed normal thyroid function but markedly diminished urinary excretion of 17-ketosteroids and 17-hydroxycorticoids. After steroid replacement therapy was insti- $\frac{\pi}{\mathbb{D}}$ tuted, a right frontal craniotomy was performed and $\mathrm{a} \underset{\mathbb{D}}{\stackrel{\rho}{\mathrm{O}}} \mathrm{O}$ chromophobe adenoma partly removed and the optic $\varrho$. chiasm decompressed. The patient was given a course of radiation therapy to the pituitary region and placed on a regimen of cortisone acetate, thyroid extract, and diphenylhydantoin sodium.

Following surgery the patient's vision improved, but in 1964 further visual deterioration was noted (Fig. 1). In February 1965 the patient was admitted to Passavant Memorial Hospital because of complaints of increasing impairment of vision and 'pulling sensations' lateral to her eyes. In addition she complained of dizziness on turning rapidly. She was unaware of oscillopsia. The patient had gained $20 \mathrm{lb}$. in the year before admission and had discontinued her medications eight months previously.

On physical examination the blood pressure was
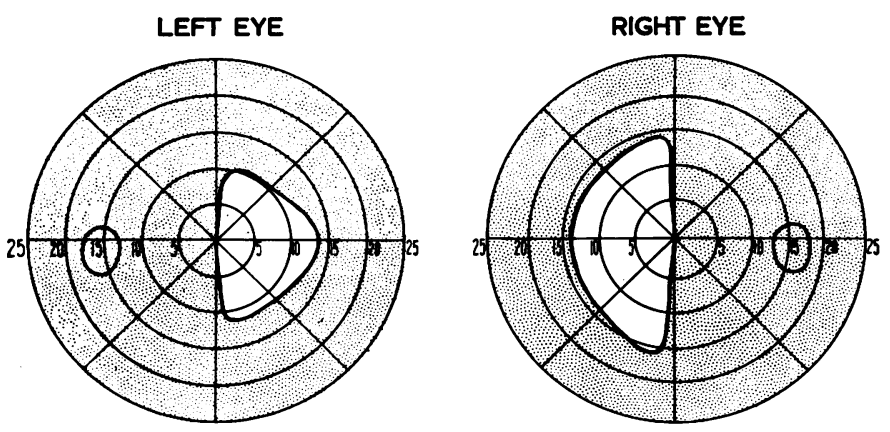

FIG. 1. Central visual fields in 1964, determined with tangent screen using a $3 \mathrm{~mm}$. white object at 1 metre.

$3 \mathrm{~mm}$. white target at $1000 \mathrm{~mm}$. 
$210 / 120 \mathrm{~mm} . \mathrm{Hg}$. The general physical examination was normal except for a moderate degree of obesity.

The patient showed a mild intellectual deficit although she was orientated in all spheres. She expressed paranoid ideas about dealings of foreign governments and involvements in 'the atomic business'. On confrontation, gross bitemporal visual field defects involving central vision were demonstrated. Visual acuity uncorrected was 20/80 in the right eye and 20/300 in the left. Both eyes could be corrected to 20/60-1. Tangent screen examination showed dense bitemporal hemianopsias with a $3 \mathrm{~mm}$. white object and some general shrinking of the remaining visual field. Ophthalmoscopic examination showed moderate disk pallor bilaterally. The pupils were equal and responded to light and to accommodation.

Hearing was bilaterally diminished with air conduction better than bone conduction. The tongue deviated slightly to the right. The patient's gait was unsteady and she staggered to either side on tandem walking. The Romberg test was negative and cerebellar function was entirely normal. The remainder of the neurological examination, except for the ocular movements, was entirely within normal limits.

OCULAR MOVEMENTS When the patient stared straight ahead, particularly into a light sufficiently bright to prevent her focusing, intermittent bursts of three or four see-saw movements were observed. As the left eye intorted and rose, the right eye extorted and fell and vice versa. See-saw movements occurred spontaneously but were intermittent. In addition, they could be readily elicited by tilting the patient's head slightly to either side, and they occurred regularly after she blinked or moved her eyes slightly in any direction. There was no consistent change in amplitude of see-saw nystagmus on upward or downward gaze. At no time were the see-saw movements continuous. In addition, on right lateral gaze transient horizontal nystagmoid jerks were noted; none occurred on gaze to the left.

Caloric stimulation according to the method of Fitzgerald and Hallpike (1942) was carried out, irrigating each ear with water at temperatures of $30^{\circ}$ and $44^{\circ} \mathrm{C}$. An imbalance between the two vestibular systems was noted, with responses on the right significantly greater than on the left and a directional preponderance to the right (Fig. 2).

LABORATORY DATA The haemogram and sedimentation rate were normal. Except for a few leucocytes per highpower field the urine analysis was normal. Serological tests for syphilis were negative. A chest radiograph was normal. An electrocardiogram showed evidence of an old posterior myocardial infarction. Fasting blood sugar, blood urea nitrogen, calcium, phosphorus, alkaline phosphatase, serum sodium, chloride and carbon dioxide contents of the blood were all normal. The serum potassium level was $3.3 \mathrm{mEq} . / 1$. Protein-bound iodine was $3.5 \mu \mathrm{g} . \%$. Tri-iodo-thyronine sponge-uptake was $28 \%$ (normal $25-35 \%$ ), and radioactive iodine uptake was $5 \%$ at 24 hours. After thyroid-stimulating hormone radioactive iodine uptake was $9 \% .17-$ Ketosteroids and 17-ketogenic steroid excretions were both $1.7 \mathrm{mg} . / 24$ hours; following A.C.T.H. stimulation they both rose to normal levels. Urinary gonadotrophins were too diminished to be detected by the mouse-uterine weight method. A glucose tolerance test was normal.

An electroencephalogram showed a severe slow wave abnormality in the right frontal area probably projected from deep subcortical regions. Skull radiographs showed a markedly enlarged sella measuring $2.2 \times 1.5 \mathrm{~cm}$. on lateral projection. There was evidence of an old osteoplastic craniotomy in the right frontal region. A pneumoencephalogram (Fig. 3) demonstrated the presence of a mass arising from the sella and protruding into the floor of the third ventricle, obliterating the chiasmatic cistern. In addition there was mild generalized dilatation in the ventricular system.

COURSE IN HOSPITAL Following the diagnostic studies the patient was given thyroid extract and hydrocortisone replacement; during this time her vision deteriorated further until she could barely see hand movements with the right eye. Three weeks after beginning replacement therapy, the patient underwent a right frontal craniotomy for further removal of the recurrent pituitary tumour. At operation a tumour mass was seen extending beyond the

MAXIMUM SPEED OF SLOW COMPONENT (Eyes closed)

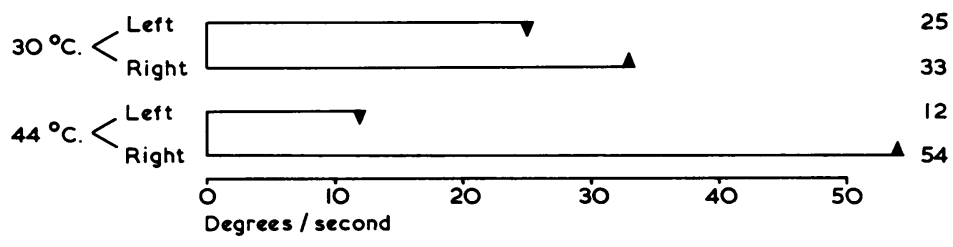

DURATION (Eyes open)

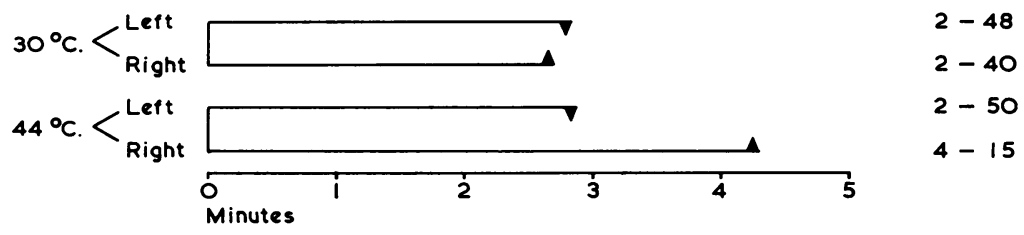

FIG. 2. Record of caloric vestibular studies indicating significantly greater responses on the right and a directional preponderance to the right. 


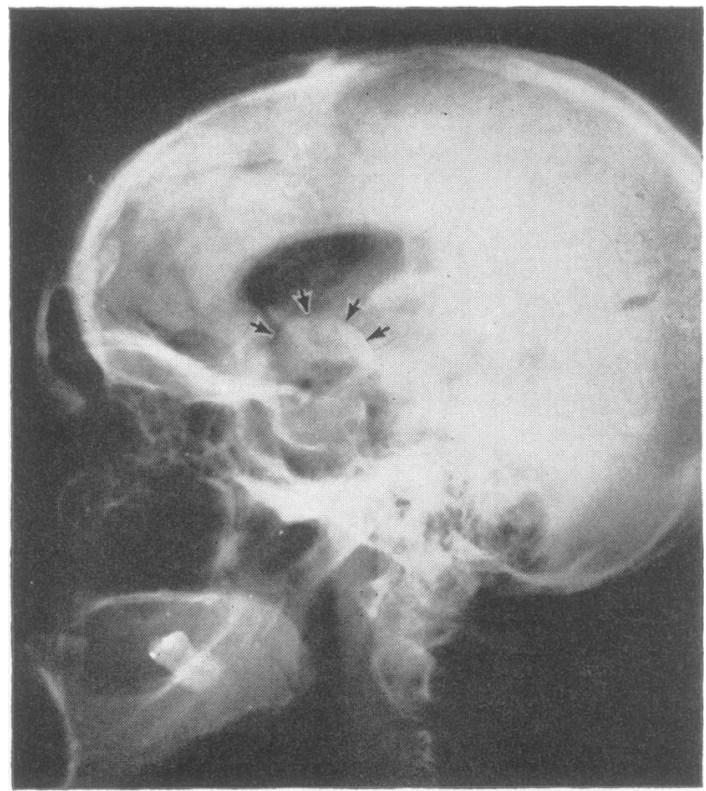

FIG. 3. Pneumoencephalogram showing a large tumour mass arising from an expanded sella and protruding into the floor of the third ventricle.

diaphragma sellae, flattening the right optic nerve and pushing the chiasm posteriorly into the floor of the third ventricle. The entire tumour mass was removed and the sella was curetted. Histologically the specimen was identified as a pituitary chromophobe adenoma.

Post-operatively the patient failed to regain consciousness. She became febrile and on the third post-operative day assumed a decerebrate posture upon noxious stimulation. The patient expired on the seventh post-operative day. A post-mortem examination was not obtained.

\section{DISCUSSION}

Although only 15 previous cases of see-saw nystagmus have been reported (Table I), three hypotheses have been advanced to explain the curious ocular movements. See-saw nystagmus has been variously attributed to an ocular or visual abnormality; a brain-stem lesion; and a diencephalic lesion.

OCULAR OR VISUAL ABNORMALITIES Lourie (1963), describing a patient with a chromophobe adenoma, noted that covering of one eye suppressed the nystagmus. He concluded that '. . . a disturbance in the normal tonic influence from the macula on attempted fixation (was) the mechanism of the nystagmus'. The patient of Slatt and Nykiel (1964), suffering from visual loss and see-saw nystagmus following an undiagnosed febrile illness, also showed variation of the nystagmus with alteration of the environ- mental illumination or of fixation. These authors similarly concluded that see-saw nystagmus was '. . . ocular rather than central in origin'. Finally, Duke-Elder (1949) has noted that see-saw nystagmus may occasionally occur in miners, where it is presumably of visual origin.

BRAIN-STEM LESIONS Case 1 of Jensen (1959) and case 2 of Daroff (1965) were apparently due to brainstem vascular lesions. In Jensen's patient cranial nerve findings indicated an incomplete unilateral lesion extending from the medulla to the midbrain. Daroff's case showed evidence only of mesencephalic abnormalities. In neither patient was any visual impairment noted, although visual fields were considered unreliable in the former case.

DIENCEPHALIC LESIONS Because parasellar tumours have occurred in nine of the reported cases of see-saw nystagmus, some authors have considered that the abnormal eye movements are due to damage to diencephalic structures. Although there is no clinical evidence that diencephalic lesions without chiasmatic, i.e., visual, involvement can produce see-saw nystagmus, Daroff (1965) has summarized consider-o able experimental evidence linking this region to control of vertical and torsional eye movements.

Each of these hypotheses fits some of the cases of see-saw nystagmus but none provides a sufficientlyo comprehensive mechanism to explain them all. The variation in clinical features documented in Table Iô. defies any simple explanation which would localize a $\rightleftharpoons$ single area of brain as the 'centre' for see-saw nystagmus. An adequate hypothesis should be able to reconcile a number of seemingly inconsistent features that have been noted in the reported cases. The most important of these are:

INCONSTANCY OF VISUAL IMPAIRMENT Visual impairment while usual is not universally present. Bitemporal hemianopia was present in 11 of 13 cases where visual fields were reported; many of the patients with field defects also had severe impairment of visual acuity in one or both eyes. One of the two patients with normal fields had severely impaired visual acuity (Slatt and Nykiel, 1964).

TRANSIENCE OF SEE-SAW NYSTAGMUS IN PATIENTS WITHOUT VISUAL IMPAIRMENT In two cases where no impairment of visual fields or visual acuity could be determined (Jensen, 1959; Daroff, 1965) see-saw nystagmus was transitory. Both of these episodes were thought to follow acute brain-stem infarction.

FREQUENCY OF A PARASELLAR TUMOUR Chiasmaticdiencephalic tumours were found in nine of 13 cases 
TABLE I

\begin{tabular}{|c|c|c|c|c|c|}
\hline \multirow[b]{2}{*}{$\begin{array}{l}\text { Author and } \\
\text { Reference }\end{array}$} & \multicolumn{4}{|c|}{ SUMMARY OF REPORTED CASES } & \multirow[b]{2}{*}{$\begin{array}{l}\text { Vestibular } \\
\text { Abnormality }\end{array}$} \\
\hline & Visual Defect & Parasellar Tumour & $\begin{array}{l}\text { Other Presumed } \\
\text { Aetiology }\end{array}$ & $\begin{array}{l}\text { Duration of } \\
\text { Nystagmus }\end{array}$ & \\
\hline Maddox (1914) & Bitemporal hemianopsia & $?$ & 一 & 一 & 一 \\
\hline Rucker (1946) & $\begin{array}{l}\text { Bilateral field defect } \\
\text { Acuity: OD- } 2 / 60 \\
\text { OS-3/60 }\end{array}$ & 0 & ? Toxoplasmosis & $>$ one year & ? (tinnitus) \\
\hline Larsen (1957) & $?$ & $\begin{array}{l}+ \\
\text { 'Oligodendrocytoma } \\
\text { chiasmatis' }\end{array}$ & 0 & Lasting & 一 \\
\hline \multicolumn{6}{|l|}{ Jensen (1959) } \\
\hline Case 1 & $\begin{array}{l}\text { Acuity: } 6 / 18 \text { O.U.; } \\
\text { Fields not determined }\end{array}$ & 0 & $\begin{array}{l}\text { Basilar-vertebral } \\
\text { thrombosis }\end{array}$ & Two days & $\begin{array}{l}+ \\
\text { Diminished caloric } \\
\text { response, left }\end{array}$ \\
\hline Case 2 & $\begin{array}{l}\text { Acuity: OD-6/18 } \\
\text { OS- } 6 / 9 \\
\text { fields? normal } \\
\text { (poor cooperation) }\end{array}$ & 0 & $\begin{array}{l}\text { Alcoholism; left } \\
\text { medial rectus paresis }\end{array}$ & One day? & - \\
\hline \multicolumn{6}{|l|}{$\begin{array}{l}\text { Smith and Mark } \\
\text { (1959) }\end{array}$} \\
\hline \multirow[t]{2}{*}{ Case 1} & $\begin{array}{l}\text { Bitemporal hemianopsia } \\
\text { Acuity: } \\
\text { OD-20/200 } \\
\text { OS-20/30 pre- } \\
\end{array}$ & $\stackrel{+}{\text { Epidermoid cyst }}$ & $\mathbf{0}$ & $\begin{array}{l}\text { Five months pre- } \\
\text { operatively } \\
\text { Ten days post- } \\
\text { operatively }\end{array}$ & $\begin{array}{l}\text { No response to ice } \\
\text { water, Barany chair }\end{array}$ \\
\hline & OD-20/30 post-operative & & & & \\
\hline Case 2 & $\begin{array}{l}\text { Improved fields } \\
\text { Bitemporal hemianopsia }\end{array}$ & & 一 & 一 & - \\
\hline \multicolumn{6}{|l|}{$\begin{array}{l}\text { (Dr. F. Walsh) } \\
\text { Mark, Smith, and } \\
\text { Kjellberg }(1960)\end{array}$} \\
\hline Case 1 & & & See case 1 above & & \\
\hline Case 2 & Bitemporal hemianopsia & $\stackrel{+}{\text { Glioma }}$ & 0 & 一 & 一 \\
\hline Lourie (1963) & $\begin{array}{l}\text { Bitemporal hemianopsia } \\
\text { Acuity: } \\
\text { OD }<3 / 200 \\
\text { OS-light perception }\end{array}$ & $\begin{array}{l}+ \\
\text { Pituitary } \\
\text { adenoma }\end{array}$ & 0 & $>$ one year & - \\
\hline \multicolumn{6}{|l|}{ Schurr (1963) } \\
\hline Case 1 & $\begin{array}{l}\text { Bitemporal hemianopsia } \\
\text { Acuity: 'normal' }\end{array}$ & $\stackrel{+}{\text { Craniopharyngioma }}$ & 0 & $\begin{array}{l}\text { Years pre-operatively } \\
\text { Stopped post- } \\
\text { operatively }\end{array}$ & $\begin{array}{l}0 \\
\text { Calorics normal }\end{array}$ \\
\hline Case 2 & $\begin{array}{l}\text { Bitemporal hemianopsia } \\
\text { Acuity: } \\
\text { OS-6/3 } \\
\text { OD-hand movements }\end{array}$ & $\begin{array}{l}+ \\
\text { Chromophobe } \\
\text { adenoma }\end{array}$ & 0 & $\begin{array}{l}\text { Years; transiently } \\
\text { relieved for } 2-3 \text { weeks } \\
\text { post-operatively }\end{array}$ & - \\
\hline \multirow[t]{2}{*}{$\begin{array}{l}\text { Kinder and } \\
\text { Howard (1963) }\end{array}$} & $\left.\begin{array}{l}\text { Bitemporal hemianopsia } \\
\text { Acuity: } \\
\text { OD-20/100 } \\
\text { OS-finger- } \\
\text { counting }\end{array}\right\} \begin{array}{l}\text { pre- } \\
\text { operatively }\end{array}$ & $\stackrel{+}{\text { Craniopharyngioma }}$ & 0 & $\begin{array}{l}\text { ? Years pre- } \\
\text { operatively } \\
\text { One day post- } \\
\text { operatively }\end{array}$ & 一 \\
\hline & $\left.\begin{array}{l}\text { OD-20/40 } \\
\text { OS-10/200 }\end{array}\right\} \begin{array}{l}\text { post- } \\
\text { operatively }\end{array}$ & & & & \\
\hline $\begin{array}{l}\text { Slatt and Nykiel } \\
\text { (1964) }\end{array}$ & $\begin{array}{l}\text { Fields normal } \\
\text { Acuity: } \\
\text { OD-20/100 } \\
\text { OS-20/200 }\end{array}$ & 0 & $\begin{array}{l}\text { Childhood febrile } \\
\text { illness }\end{array}$ & 31 years & $\begin{array}{l}\text { No response to ice } \\
\text { water, calorics, } \\
\text { Barany chair }\end{array}$ \\
\hline \multicolumn{6}{|l|}{ Daroff (1965) } \\
\hline Case 1 & $\begin{array}{l}\text { Bitemporal hemianopsia } \\
\text { Acuity: } \\
\text { OD-20/200 } \\
\text { OS-20/50 }\end{array}$ & $\begin{array}{l}+ \\
\text { Chromophobe } \\
\text { adenoma }\end{array}$ & 0 & Months until death & - \\
\hline Case 2 & $\begin{array}{l}\text { Fields normal } \\
\text { Acuity: } 20 / 20 \text { O.U. }\end{array}$ & 0 & Midbrain infarction & Four weeks & - \\
\hline $\begin{array}{l}\text { Drachman } \\
\text { (present report) }\end{array}$ & Bitemporal hemianopsia & $\begin{array}{l}+ \\
\text { Chromophobe } \\
\text { adenoma }\end{array}$ & 0 & Months until death & $\begin{array}{l}\text { Asymmetrical caloric } \\
\text { responses }\end{array}$ \\
\hline
\end{tabular}


where adequate studies were performed to search for a mass lesion. No other tumours have been associated with see-saw nystagmus.

OCCURRENCE OF VESTIBULAR ABNORMALITIES Vestibular abnormalities were found in four of six patients in whom results of caloric (and in some cases rotational) tests were reported.

Thus ocular, chiasmatic, diencephalic, brain-stem, and vestibular lesions have been associated with one or more cases of see-saw nystagmus.

\section{CONCLUSIONS}

From a physiological standpoint it is not surprising that see-saw nystagmus has been associated with lesions in these areas, since vertical and torsional ocular movements have been experimentally produced by stimulation or ablation of closely corresponding structures:

Vertical eye movements may be readily produced by bilateral caloric stimulation of the labyrinths (Bender and Shanzer, 1964). Electrically, stimulation of the superior colliculi, the mesencephalic reticular formation, the region of the third ventricle, the head of the caudate nucleus or (with bilateral stimulation) the frontal eye movement area (Brodmann's area 8) may produce vertical eye movements (Cogan, 1956; Szekely and Spiegel, 1963; Bender and Shanzer, 1964; Pasik and Pasik, 1964). Disconjugate vertical movements (one eye rising, the other falling) have been produced by unilateral stimulation lateral to the superior vestibular nucleus (Montandon and Monnier, 1964). Facilitation of nystagmus produced by stimulation in the region of the vestibular nuclei follows destruction of the contralateral 'diencephalic nystagmogenic area' medial to the lateral geniculate body (Montandon and Monnier, 1964).

Torsional eye movements are thought to originate normally in the saccule and utricle (Kompanejetz, 1928; Miller, 1962) and may be produced by tilting of the head. Electrical stimulation of the zona incerta and of the interstitial nucleus of Cajal have also produced ocular torsion in experimental animals (Hyde and Toczek, 1962; Toczek and Hyde, 1963).

Visual control of vertical eye movements takes place via connexions of the occipital lobes with the frontal eye fields (Cogan, 1956). Although no cortical representation of torsional eye movements has been demonstrated, the fact that rotation of the visual environment may produce ocular torsion indicates a probable cortical mechanism for this eye movement as well. Other experimental studies indicate that visual fixation is capable of strongly inhibiting the eye movements induced by electrical stimulation of nystagmogenic areas (Montandon and Monnier, 1964).
This brief summary indicates that numerous areas of the nervous system are concerned with vertical and torsional ocular movements. Yet experimental stimulation or ablation of a single area has not as yet fully reproduced the picture of see-saw nystagmus, combining its torsional and vertical components in a pendular rhythm. It seems likely that the production of see-saw nystagmus may require more than one lesion; this conclusion is in keeping with Bender and Shanzer's statement (1964) that '. . . integration of nervous system activity that results in eye movements . . . occurs at many levels. ... There may be a system of oculomotor activity but not an anatomic centre subserving such function'.

In the present case visual and vestibular abnormalities occurred in a single patient. Other combined disorders may perhaps be produced by a single tumour mass if it is sufficiently large; a parasellar mass, for example, may compress the chiasma and in addition damage ascending vestibular pathways in the diencephalic region (Spiegel, Szekely, and Gildenberg, 1965).

This concept that combined lesions may be necessary for the production of see-saw nystagmus explains its relative rarity as well as the diversityo of lesions that have been held responsible. The im- $\mathbb{\pi}$ portance of specifically visual impairment as a com- $-\frac{\rho}{D}$ ponent may be that it permits latent see-saw ocular movements to become manifest when visual inhibition is removed. Similarly, the transitory natureo of see-saw nystagmus produced by brain-stem? lesions alone may be due to the fact that visualo inhibition of ocular movements supervenes after a? brief interval.

\section{SUMMARY}

A case of see-saw nystagmus is presented in which a vestibular abnormality occurred in combination with bitemporal hemianopia. The neurophysiology of vertical and torsional ocular movements is briefly reviewed. The suggestion is made that see-saw nystagmus may be due to several possible combinations of lesions involving visual, vestibular, or other structures, rather than to a single lesion.

I am grateful to Dr. Cecil Hart who performed the vestibular function studies.

\section{REFERENCES}

Bender, M. B., and Shanzer, S. (1964). In The Oculomotor System, edited by M. B. Bender, pp. 126, 131, 137. Harper and Row, New York.

Cogan, D. G. (1956). Neurology of the Ocular Muscles, 2nd ed. Thomas, Springfield, Illinois.

Daroff, R. B. (1965). See-saw nystagmus. Neurology (Minneap.), 15, 874-877.

Duke-Elder, W. S. (1949). Textbook of Ophthalmology, vol. 4. p. 4233. Kimpton, London. 
Fitzgerald, G., and Hallpike, C. S. (1942). Studies in vestibular function. I. Observations on the directional preponderance ('Nystagmusbereitschaft') of caloric nystagmus resulting from cerebral lesions. Brain, 65, 115-137.

Hyde, J. E., and Toczek, S. (1962). Functional relation of interstitial nucleus to rotatory movements evoked from zona incerta stimulation. $J$. Neurophysiol., 25, 455-466.

Jensen, O. A. (1959). See-saw nystagmus. Brit. J. Ophthal., 43, 225229.

Kinder, R. S. L., and Howard, G. M. (1963). See-saw nystagmus. Amer. J. Dis. Child., 106, 331-332.

Kompanejetz, S. (1928). Investigation on the counterrolling of the eyes in optimum head-positions. Acta oto-laryng. (Stockh.), $12,332-250$.

Larsen, V. (1957). Et tilfaelde af vippenystagmus. Ugeskr. Lag., 119, 947-950. Abstracted in Of. Laeg., 11/ 3275.

Lourie, H. (1963). See-saw nystagmus. Arch. Neurol. (Chic.), 9, 531533.

Maddox, E. E. (1914). See-saw nystagmus with bitemporal hemianopia. Proc. roy. Soc. Med., 7, Sect. Neurol. Ophthal. Obol., pp. xii-xiii.

Mark, V. H., Smith, J. L., and Kjellberg, R. D. (1960). Suprasellar epidermoid tumour. A case report with the presenting complaint of see-saw nystagmus. Neurology. (Minneap.), 10, 81-83.

Miller, E. F. (1962). Counterrolling of the human eyes produced by head tilt with respect to gravity. Acta oto-laryng. (Stockh.), $54,479-501$.

Montandon, P. and Monnier, M. (1964). Correlations of the diencephalic nystagmogenic area with the bulbo-vestibular nystagmogenic area. Brain, 87, 673-690.

Pasik, P., and Pasik, T. (1964). In The Oculomotor System, edited by M. B. Bender, pp. 59-60. Harper and Row, New York.

Rucker, C. W. (1946). See-saw nystagmus associated with choroiditis and positive neutralization test for toxoplasma. Arch. Ophthal., (Chic.), 35, 301-302.

Schurr, P. H. (1963). See-saw nystagmus. Proc. roy. Soc. Med., 56, 808-810.

Slatt, B., and Nykiel, F. (1964). See-saw nystagmus. Amer. J. Opthal., 58, 1016-1021.

Smith, J. L., and Mark, V. H. (1959). See-saw nystagmus with suprasellar epidermoid tumour. A.M.A. Arch. Ophthal., 62, 280283.

Spiegel, E. A., Szekely, E. G., and Gildenberg, P. L. (1965). Vestibular responses in midbrain, thalamus, and basal ganglia. Arch. Neurol. (Chic.), 12, 258-269.

Szekely, E. G., and Spiegel, E. A. (1963). Vertical nystagmus induced by injection of stimulating substances into the striatum, third, or lateral ventricle. Neurology, (Minneap.), 13, 306-314.

Toczek, S., and Hyde, J. E. (1963). Effect of vestibular nerve section on torsion and on evoked rotatory movements. Exp. Neurol. 8, 143-154. 